\title{
Korean Guidelines for Diagnosis and Management of Interstitial Lung Diseases: Part 2. Idiopathic Pulmonary Fibrosis
}

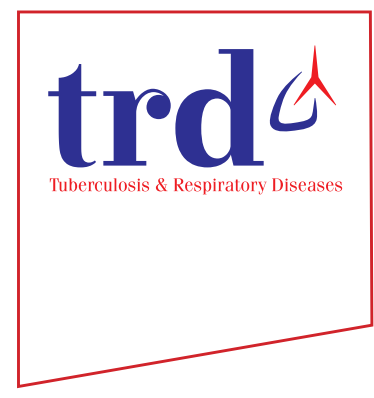

\begin{abstract}
Sang Hoon Lee, M.D. ${ }^{1}{ }^{(\mathbb{D}}$, Yoomi Yeo, M.D. ${ }^{2}$, Tae-Hyung Kim, M.D., Ph.D. ${ }^{2}$, Hong Lyeol Lee, M.D., Ph.D. ${ }^{3}$, Jin Hwa Lee, M.D., Ph.D. ${ }^{4}$, Yong Bum Park, M.D. ${ }^{5}$, Jong Sun Park, M.D., Ph.D. ${ }^{6}$, Yee Hyung Kim, M.D., Ph.D. ${ }^{7}$, Jin Woo Song, M.D., Ph.D. ${ }^{8}$, Byung Woo Jhun, M.D., Ph.D. ${ }^{9}$, Hyun Jung Kim, M.D., Ph.D. ${ }^{10}$, Jinkyeong Park, M.D., Ph.D. ${ }^{9}$, Soo-Taek Uh, M.D., Ph.D. ${ }^{11}$, Young Whan Kim, M.D., Ph.D. ${ }^{12}$, Dong Soon Kim, M.D., Ph.D. ${ }^{8}$ and Moo Suk Park, M.D., Ph.D. ${ }^{1}{ }^{\circledR}$, on behalf of Korean Interstitial Lung Diseases Study Group

${ }^{1}$ Division of Pulmonology, Department of Internal Medicine, Severance Hospital, Institute of Chest Diseases, Yonsei University College of Medicine, Seoul, ${ }^{2}$ Division of Pulmonary and Critical Care Medicine, Hanyang University Guri Hospital, Hanyang University College of Medicine, Guri, ${ }^{3}$ Division of Pulmonary and Critical Care Medicine, Department of Internal Medicine, Inha University Hospital, Inha University College of Medicine, Incheon, ${ }^{4}$ Division of Pulmonary and Critical Care Medicine, Department of Internal Medicine, Ewha Womans University College of Medicine, Seoul, ${ }^{5}$ Department of Internal Medicine, Hallym University Kangdong Sacred Heart Hospital, Lung Research Institute of Hallym University College of Medicine, Seoul, ${ }^{6}$ Division of Pulmonary and Critical Care Medicine, Department of Internal Medicine, Seoul National University Bundang Hospital, Seoul National University College of Medicine, Seongnam, ${ }^{7}$ Division of Pulmonary and Critical Care Medicine, Kyung Hee University Hospital at Gangdong, Seoul, ${ }^{8}$ Department of Pulmonary and Critical Care Medicine, Asan Medical Center, University of Ulsan College of Medicine, Seoul, ${ }^{9}$ Division of Pulmonary and Critical Care Medicine, Samsung Medical Center, Sungkyunkwan University School of Medicine, Seoul, ${ }^{10}$ Department of Internal Medicine, Keimyung University School of Medicine, Daegu, ${ }^{11}$ Department of Internal Medicine, Soonchunhyang University Seoul Hospital, Seoul, ${ }^{12}$ Division of Pulmonary and Critical Care Medicine, Department of Internal Medicine, Seoul National University Hospital, Seoul, Korea
\end{abstract}

Idiopathic pulmonary fibrosis (IPF) is a chronic, progressive fibrosing interstitial pneumonia, which presents with a progressive worsening dyspnea, and thus a poor outcome. The members of the Korean Academy of Tuberculosis and Respiratory Diseases as well as the participating members of the Korea Interstitial Lung Disease Study Group drafted this clinical practice guideline for IPF management. This guideline includes a wide range of topics, including the epidemiology, pathogenesis, risk factors, clinical features, diagnosis, treatment, prognosis, and acute exacerbation of IPF in Korea. Additionally, we suggested the PICO for the use of pirfenidone and nintendanib and for lung transplantation for the treatment of patients with IPF through a systemic literature review using experts' help in conducting a meta-analysis. We recommend this guideline to physicians, other health care professionals, and government personnel in Korea, to facilitate the treatment of patients with IPF.

Keywords: Idiopathic Pulmonary Fibrosis; Diagnosis; Disease Management; Korea

Address for correspondence: Moo Suk Park, M.D., Ph.D.

Division of Pulmonology, Department of Internal Medicine, Severance Hospital, Institute of Chest Diseases, Yonsei University College of Medicine, 50-1 Yonsei-ro, Seodaemun-gu, Seoul 03722, Korea

Phone: 82-2-2228-1955, Fax: 82-2-393-6884, E-mail: pms70@yuhs.ac

Received: Dec. 7, 2018, Revised: Dec. 10, 2018, Accepted: Dec. 13, 2018, Published online: Feb. 28, 2019

@(c) it is identical to the Creative Commons Attribution Non-Commercial License (http://creativecommons.org/licenses/by-nc/4.0/) 


\section{Introduction}

Idiopathic pulmonary fibrosis (IPF) is the most common idiopathic interstitial pneumonia (IIP), which is characterized by progressively worsening dyspnea and decreased lung function. It occurs mainly in the elderly and in men $^{1}$. After the 2002 American Thoracic Society/European Respiratory Society (ATS/ERS) guideline, an official guideline revision was provided in 2011 by the American Thoracic Society/European Respiratory Society/Japanese Respiratory Society/Latin American Thoracic Association (ATS/ERS/JRS/ALAT), which deals with the diagnosis and management of $\operatorname{IPF}^{1,2}$. In the past, there was no proven agent for IPF, but now, some helpful medications for its management are available ${ }^{3}$.

Since the publication of the 2011 guideline, more studies were performed regarding the treatment of IPF. In the 2011 guideline, for pirfenidone, "conditional recommendation against use" was included; however, this became "conditional recommendation for use" in the 2015 clinical practice guideline, which was reported by ATS/ERS/JRS/ALAT. Furthermore, nintendanib was the conditionally recommended agent in the 2015 guideline ${ }^{3}$.

Korean Interstitial Lung Disease Study Group performed a national survey about IIP in 2008. According to this 2008 IIP National Survey, 1,685 patients ( $77.1 \%)$ were diagnosed with $\mathrm{IPF}^{4}$. Although IPF is the most common form of IIP, there has been no guideline in Korea to date concerning the management of IPF. In this guideline, we discussed the many aspects of IPF: epidemiology, pathogenesis, risk factors, clinical features, diagnosis, treatment, prognosis, and acute exacerbation of IPF. Furthermore, we conducted a meta-analysis, and suggested PICO for the use of pirfenidone and nintendanib and for lung transplantation for the treatment of IPF. We recommend this guideline to physicians, other health care professionals, and government personnel in South Korea, for the care of IPF patients.

\section{Epidemiology of Idiopathic Pulmonary Fibrosis}

IPF is the most common and severe form of IIP. IPF prevalence and incidence varies according to regions and countries. Its prevalence rate is reported from 0.7 to 63.0 per 100,000 population, with most studies reporting about 10 per 100,000 population $^{5-10}$. The annual incidence is also reported from 0.6 to 10.7 per 100,000 population ${ }^{5,7}$. One of the important reasons for these variations in outcome is that many studies were conducted in western countries before the establishment of the revised IPF diagnostic criteria in $2011^{5,6,8,9,11}$. According to the 2008 IIP National Survey in Korea, 1,685 out of 2,186 patients (77.1\%) with IIP were diagnosed with IPF, from 2003 to $2007^{4}$. Another study reported the annual incidence of IPF in
Korea as 1.7 per 100,000 population ${ }^{12}$.

The prevalence and incidence of IPF tend to be higher in males than in females, and tend to increase with aging. Initial diagnosis of IPF is most common in people aged 70 years and above $^{8,13,14}$. In a national study, 1,220 of the 1,685 IPF patients $(72.4 \%)$ were male and the mean age at diagnosis was 69 years ${ }^{4}$. The association between exposure to various external environmental substances and the occurrence of IPF has been reported ${ }^{4}$. With smoking, both past and present smoking were reported to be associated with $\mathrm{IPF}^{15}$. In one study, the relative risk of IPF occurrence in smokers was 2.94 times higher than healthy adults ${ }^{14}$.

Livestock, wood dust, metal dust, stones, and diesel particulates are also reported to be associated with $\mathrm{IPF}^{9,16}$. Lee et all. ${ }^{17}$ showed that IPF patients with dust exposure are diagnosed with IPF at lower ages and had longer respiratory symptom compared with IPF patients without dust exposure. In their study, dust exposure was identified as a risk factor associated with death. Recently, IPF has been reported to be associated with other diseases, including reflux esophagitis, diabetes mellitus, pulmonary tuberculosis, non-tuberculosis disease, heart disease, lung cancer, and chronic obstructive pulmonary disease $^{18-20}$. In addition, the association of viral disease with IPF was also suggested. Herpesviruses such as Epstein-Barr virus/ cytomegalovirus were detected frequently in the lung tissue of IPF patients ${ }^{21,22}$. Furthermore, the positivity of serum hepatitis $\mathrm{C}$ virus antibodies has been reported to be high in patients with $\mathrm{IPF}^{23}$, and its relevance has been suggested, but there is still insufficient evidence to explain the causal relationship.

\section{Definition and Pathogenesis of Idiopathic Pulmonary Fibrosis}

\section{Definition of IPF}

IPF is defined as a "specific form of chronic, progressive fibrosing interstitial pneumonia of unknown cause, occurring primarily in older adults, limited to the lungs, and associated with the histopathologic and/or radiologic pattern of usual interstitial pneumonia (UIP)." The definition of IPF requires the exclusion of other forms of interstitial pneumonia including other idiopathic interstitial pneumonias and interstitial lung diseases associated with environmental exposure, medication, or systemic disease ${ }^{1}$.

\section{Pathogenesis of IPF}

\section{1) Introduction}

IPF results from the recurrent injury to epithelial cells caused by a variety of exposures, such as cigarette smoke, dust, and gastroesophageal reflux (GER). These exposures activate abnormal pathways in a genetically predisposed indi- 
vidual or an aged individual, resulting in the failed resolution of the wound-healing respons $\mathrm{e}^{24}$. Growth factors secreted by the injured epithelial cells recruit fibroblasts which differentiate into myofibroblasts. Myofibroblasts secrete collagen, which accumulates in the extracellular matrix $(\mathrm{ECM})^{24,25}$.

\section{2) Epithelium}

An early consequence of injury to the alveolar epithelial cells (AEC) is the development of an intraalveolar exudate. Organization of the intraalveolar exudate leads to alveolar collapse with apposition of the denuded alveolar walls and loss of surfactant. Both epithelial and basement membrane injuries appear necessary for the development of intraluminal fibrosis. Following an injury, type II cells proliferate and differentiate into type I cells for reepithelialization of the injured alveoli. In IPF, loss of type I cells and marked proliferation of type II cells are noted; however, these cells do not appear to reepithelialize the alveolar space. This may be due to the continuing abnormalities in the basement membrane, which in turn permit the migration of mesenchymal cells from the interstitium to the alveolar regions of the injured lung. Excessive deposition of collagen by mesenchymal cells appears to prevent the reexpansion of the collapsed airspace ${ }^{24,25}$.

Another well recognized aberrancy of the AEC in IPF patients may be the overproduction and release of fibrogenic cytokines and growth factors. Following epithelial injury, progression of fibrosis follows, due to an imbalance between many groups of molecules including proinflammatory and anti-inflammatory cytokines, fibrogenic and antifibrogenic polypeptides, oxidants-antioxidants, and angiogenic and angiostatic molecules. Transforming growth factor (TGF)- $\beta 1$ is one of the most potent regulators, and can induce a number of growth factors and cytokines to participate in fibrosis ${ }^{24-26}$.

(1) Genetics: Genetic predisposition to IPF is supported by familial clustering, the occurrence of lung fibrosis in genetic multi-system disorders, and differing susceptibilities in humans exposed to similar levels of fibrogenic agents ${ }^{24}$. Surfactant protein C (SPC) and surfactant protein A2 (SPA2) are exclusively synthesized by type II AECs. Mutations in these two genes have been described in association with $\mathrm{IPF}^{24} . S P C$ and $S P A$ mutations have been shown to cause incorrect protein folding and processing, thereby activating the cells' endoplasmic reticulum (ER) stress response ${ }^{27}$. Telomerases help to offset the shortening that occurs during DNA replication. Rare mutations in the telomerase genes, telomerase reverse transcriptase (TERT) and telomerase RNA component (TERC) have been identified in IPF cases ${ }^{28}$. Even in the absence of TERT/TERC mutations, some IPF patients have shorter telomeres compared with age-matched controls, suggesting that IPF may be a disease of aging ${ }^{29}$. A common variant in the promoter of the gene encoding mucin $5 \mathrm{~B}(M U C 5 B)$ on chromosome 11 was present in patients with familial and sporadic $\mathrm{IPF}^{30}$.
(2) ER stress: ER stress occurs when there is an imbalance between cellular demand for protein synthesis and the ER's capacity to synthesize, process, and package the requisite proteins. In response to this stress, the cell activates the unfolded protein response (UPR) to match the protein production capacity of the ER. ER stress reaction generally helps the cell to survive. However, if the stress condition is overwhelming or prolonged, and the UPR cannot match the demand, a terminal UPR is activated and the cell sacrifices itself through apoptotic pathways ${ }^{27}$. ER stress and activation of the UPR also contribute to fibrotic remodeling in the lungs ${ }^{24,25,31}$.

(3) TGF- $\beta$ activation: Levels of active TGF- $\beta$ are increased in the lungs of patients with IPF. Activation of AECs expressing integrin $\alpha \mathrm{V} \beta 6$ induces TGF- $\beta$ activation. Possible processes associated with TGF- $\beta$ activation include inhibition of AEC proliferation, differentiation of fibroblasts to myofibroblasts, and activation of programming that promotes epithelialmesenchymal transition (EMT) ${ }^{31,32}$

(4) EMT: EMT is the process by which epithelial cells acquire molecular and cell physiologic features, commonly associated with mesenchymal cells, following activation by specific growth factors, of which TGF- $\beta$ is the prototype. EMT programming is activated during tissue injury and remodeling conditions. The evidence that alveolar cells exhibit EMT in IPF patients is based on studies co-localizing epithelial cell- and mesenchymal cell-associated proteins within IPF lungs ${ }^{31,33}$.

(5) External stressors: To develop IPF, the primary pathologic change is a genetic mutation that causes the epithelial cells to become intrinsically abnormal. These genetic abnormalities lead to activation of molecular pathways such as the UPR, TGF- $\beta$ secretion, and EMT, and ultimately tolung fibrosis. However, genetic mutations may not be sufficient to cause lung fibrosis; rather, a second event-that is, an environmental exposure-may act in concert with a genetically predisposed epithelium $^{25,31}$.

\section{3) Mesenchyme}

(1) Fibrocyte: Fibrocytes contribute to the development of lung fibrosis by directly producing ECM proteins, by differentiating into fibroblasts or myofibroblasts, or by producing cytokines, which induce collagen deposition. Fibrocytes have been found both in the circulation and in the lung parenchyma of patients with $\mathrm{IPF}^{34}$.

(2) Fibroblast: During normal wound healing, unneeded fibroblasts are removed through the activation of apoptotic pathways. Unlike the normal fibroblasts, IPF fibroblasts resist apoptosis and have greater proliferative capacity. Following the induction of fibroblast activity by epithelial injury, fibroblasts and myofibroblasts appear to organize themselves into fibroblastic foci which precede the appearance of end-stage fibrosis $\mathrm{s}^{24,25,31}$.

(3) Myofibroblast: Myofibroblasts are cells that express features of both fibroblasts and smooth muscle cells, and are 
identified by their expression of $\alpha$-smooth muscle actin. Fibroblasts differentiate into myofibroblasts under the influence of mediators, such as TGF- $\beta$. EMT is thought to be another source of myofibroblasts ${ }^{31,33}$. Compared with the resident lung fibroblasts, myofibroblasts secrete excessive amounts of matrix. They localize to fibroblastic foci, and are responsible for the synthesis and deposition of ECM and the resultant structural remodeling ${ }^{24,25,31}$.

(4) Collagen: In the lungs of patients with IPF, excess collagen is deposited in the ECM. Collagen is also degraded extracellularly by a family of matrix metalloproteinases (MMPs). Pathologic fibrotic scars may represent an improper balance between deposition and degradation of ECM components. However, this concept is not only insufficient but probably wrong. The basement membrane, which forms the ECM underlying the epithelium and endothelium of parenchymal tissue, precludes direct access to the damaged tissue. To disrupt this physical barrier, MMPs cleave one or more ECM constituents allowing the extravasation of cells into, and out of, damaged sites. MMPs may have beneficial and detrimental effects, and some individual MMPs such as MMP1 and MMP7 contribute to the progression and poor outcome of IPF while others such as MMP19 seems to be protective $\mathrm{e}^{24,25,31,35}$.

(5) The clotting cascade: The clotting cascade appears to be activated in pulmonary fibrosis. Cleaved clotting factors have major pro-inflammatory and profibrogenic effects, and activated platelets/endothelial cells release fibrogenic mediators, including platelet-derived growth factor (PDGF) and TGF- $\beta^{36}$.

\section{4) Epigenetics}

Exposure to environmental stresses such as tobacco smoke, air pollution, and aging can lead to epigenetic DNA changes in IPF lungs ${ }^{37}$. DNA methylation and/or other epigenetic changes are important in the pathogenesis of IPF and their enduring influences on gene expression could in part explain the relentless progression of the illness ${ }^{31}$.

\section{Risk Factors for Idiopathic Pulmonary Fibrosis}

IPF could be due to complex interactions between genetic predisposition, environmental factors, and pulmonary infec$\operatorname{tion}^{1,38}$. Therefore, therapeutic agents are being developed focusing on progress rather than disease initiation. Here are some major known risk factors.

\section{Age and sex}

The average age of IPF diagnosis is about 65 years $^{8}$. The reason for not recommending surgical biopsy as a method of confirmation of recent IPF is because of the age at the time of
IPF diagnosis and the accumulation of experience with typical high-resolution computerized tomography (HRCT) findings $^{1,39}$. Aging is a major risk factor of IPF based on epidemiological evidence from the mean age at diagnosis, as well as the experimental results showing that alveolar damage is not well cured by cellular senescence. Abnormal short telomeres were observed in the alveolar epithelium of patients with $\operatorname{IPF}^{29}$, and telomerase (an enzyme that maintains telomere length) mutations, were found in familial $\mathrm{IPF}^{28}$. Aging does not effectively result in protein folding in the $\mathrm{ER}^{40}$. Finally, pathologic accumulation of unfolded protein increases ER stress and apoptosis. These proteins and apoptosis were increased in the alveolar epithelium of IPF patients ${ }^{41,42}$. In familial IPF, abnormalities, in the process of making SPA2, have been found, which causes unfolded protein to accumulate ${ }^{43}$. In addition, aging oxidizes proteins such as glutathione and modifies the function of mesenchymal stem cells, leading to abnormalities in the alveolar epithelial regeneration ${ }^{44,45}$.

The incidence and prevalence of IPF is higher in men than in women $(1.6: 1 \text { to } 2: 1)^{8}$, but the prognosis in women is bet$\operatorname{ter}^{46}$. It is likely that IPF is common in men because they have relatively high smoking rates and are engaged in occupations that exposes them to inhaled substances.

\section{Environmental factor}

\section{1) Smoking}

Exposure to inhaled substances is an important risk factor of IPF, and smoking is the most common ${ }^{15}$. In particular, the risk of IPF increases with more than 20 pack-years of smoking, and the risk of IPF due to smoking correspond to both familial and sporadic IPF ${ }^{47}$. The fact that IPF risk persists after cessation of smoking suggests that inflammation persists after smoking cessation ${ }^{48,49}$. Smoking itself causes not only epithelial cell damage but also widespread genetic alterations such as chromatin transformation and DNA methylation, which regulates the gene expression involved in tissue healing pro$\operatorname{cesses}^{50}$. However, it has been reported that metal dust (brass, lead, and steel), wood dust (pine), farming, raising birds, cosmetology, masonry, and exposure to plant dusts and animal hairs are also related to IPF ${ }^{16}$.

\section{2) Infection}

Infection is the most common cause of inflammatory reaction, which is considered to be a major factor in the development and progression of pulmonary fibrosis because it initiates alveolar damage and sustains the inflammatory response $^{51}$. Numerous viruses and bacteria can cause epithelial cell damage and apoptosis and can modulate the host immune response $\mathrm{e}^{52}$. The infection experimentally contributes to the onset of IPF by accelerating fibrosis, with other fibrogenic factors $^{53,54}$. In the past, immunosuppressive therapy for IPF was not effective, and clinical evidence of persistent inflam- 
mation was insufficient, suggesting that the role of chronic inflammation in the pathogenesis of IPF was minimal ${ }^{55}$. However, it cannot be denied that inflammatory cytokines and immune cell infiltration are found in the lungs of IPF patient $\mathrm{s}^{56}$. Animal experiments have shown that interleukin- $1 \beta$ induces early inflammation and fibrosis through TGF- $\beta 1$, and sustains the aggregation of myofibroblasts and collagen at day 60 , irrespective of the presence of residual inflammation, resulting in tissue changes similar to the myofibroblastic foci observed in humans ${ }^{57}$. It is thought that fibrosis progresses due to the complex interactions between initial injury and the adverse reaction of the healing process, resulting in IPF.

\section{Genetic factors}

IPF is considered to be a complex genetic disorder associated with at least 11 mutations in the nucleotide sequence of seven genes (MUC5B, TERT, TERC, RTEL1, PARN, SFTPC, and $S F T P A 2)^{58}$. MUC5B mutation, which causes abnormalities in the mucociliary function of the peripheral airways, accounts for $30 \%-35 \%$ of the risk of IPF ${ }^{58}$. Among the total IPF patients, $1 \%$ of surfactant gene mutation, $35 \%$ of promoter mutation of $M U B 5 B$ mucin gene, $3 \%$ of telomerase gene mutation, and no known gene mutation in the remaining $60 \%$ of patients were reported ${ }^{30,31,59}$. Surfactant protein and mucin gene mutations result in a direct epithelial cell damage and apoptosis $^{43,59}$, while telomerase gene mutations lead to an abnormal recovery pathway after epithelial damage $e^{28}$.

\section{Gastroesophageal reflux}

It is known that the prevalence of GER is higher in patients with IPF compared to the general population ${ }^{19}$. Repeated microaspiration can cause fibrosis by continuing lung injury ${ }^{60,61}$. Although there have been reports that the treatment of GER slows the progress of $\mathrm{IPF}^{62}$, recent studies have shown that antacid therapy or surgery for GER does not slow down the progress of IPF $^{63,64}$.

\section{Clinical Features and Diagnosis of Idiopathic Pulmonary Fibrosis}

\section{Clinical features of IPF}

IPF should be considered in patients with the following clinical features:

- Age over 50 years

- Persistent dyspnea on exertion

- Persistent cough

- Clubbing of the fingers

- Bilateral inspiratory crackles on auscultation

- Restrictive ventilatory defect with decreased diffusion ca- pacity

\section{Definition of UIP Pattern}

\section{1) UIP pattern: HRCT features}

UIP is characterized on HRCT by the presence of reticular opacities, often associated with traction bronchiectasis (Figure 1). Honeycombing is common and is critical in making a definitive diagnosis. The distribution of UIP on HRCT is basal and subpleural predominance. Micronodules, air trapping, discrete cysts, extensive ground glass opacities more than the reticulation, consolidation, or peribronchovascular distribution should be considered an alternative diagnosis.

In patients whose HRCT does not show a UIP pattern, surgical lung biopsy is necessary to make a definitive diagnosis.

(1) UIP pattern (all four criteria)

- Subpleural, basal predominance

- Reticular abnormality

- Honeycombing \pm traction bronchiectasis

- Absence of features that are inconsistent with the UIP pattern

(2) Possible UIP pattern (all four criteria)

- Subpleural, basal predominance

- Reticular abnormality

- Absence of features that are inconsistent with the UIP pattern

\section{2) UIP pattern: histopathology features}

The most important histopathologic finding is a heterogeneous appearance at low magnification in which areas of fibrosis and honeycomb change alternate with areas of less affected or normal parenchyma. These histopathologic changes affect the subpleural and paraseptal parenchyma. The fibrotic area is composed of dense collagen and fibroblastic foci.

Hyaline membranes, organizing pneumonia, granulomas, marked interstitial inflammation, and predominant airway centered changes should be considered as an alternative diagnosis (Figure 2).

(1) UIP pattern (all four criteria)

- Evidence of marked fibrosis/architectural distortion \pm honeycombing in a predominantly subpleural/parasepatal distribution

- Presence of patchy involvement of the lung parenchyma by fibrosis

- Presence of fibroblast foci

- Absence of features against the diagnosis of UIP suggesting an alternative diagnosis

(2) Probable UIP pattern

- Evidence of marked fibrosis/architectural distortion \pm honeycombing in a predominantly subpleural/parasepatal distribution

- Absence of either patchy involvement or fibroblast foci, but not both 
A

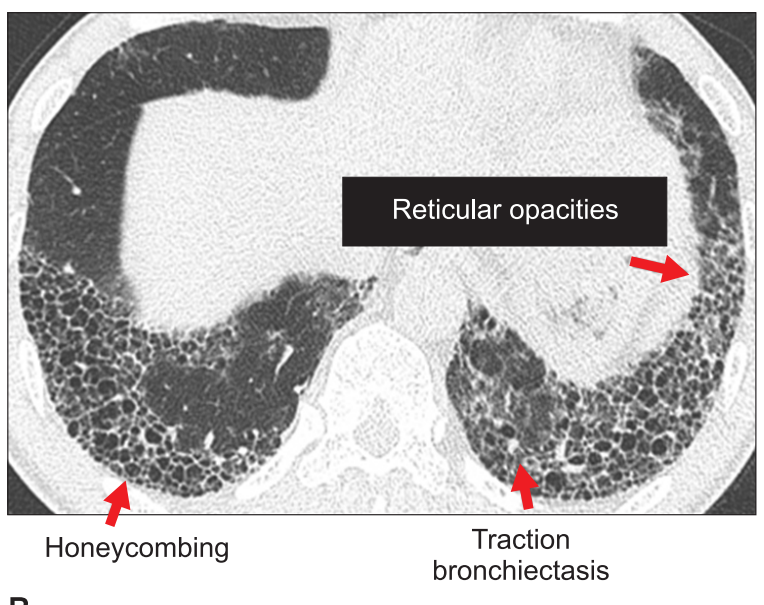

B

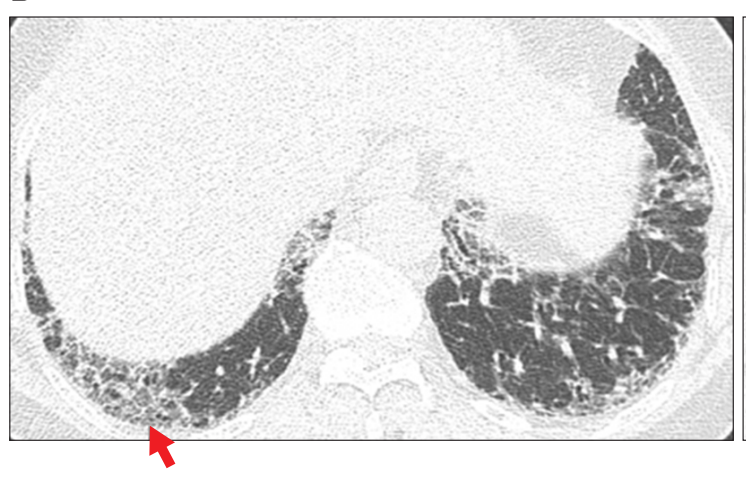

Reticular opacities

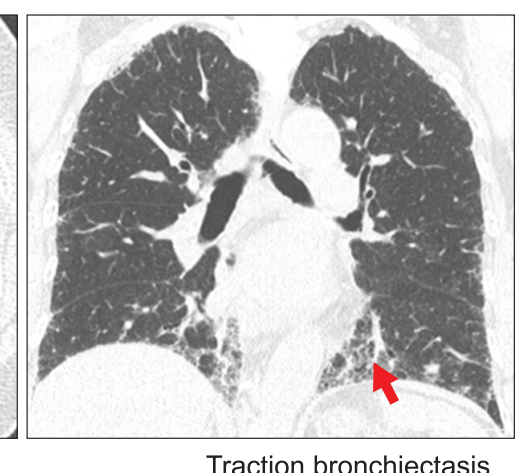

Traction bronchiectasis

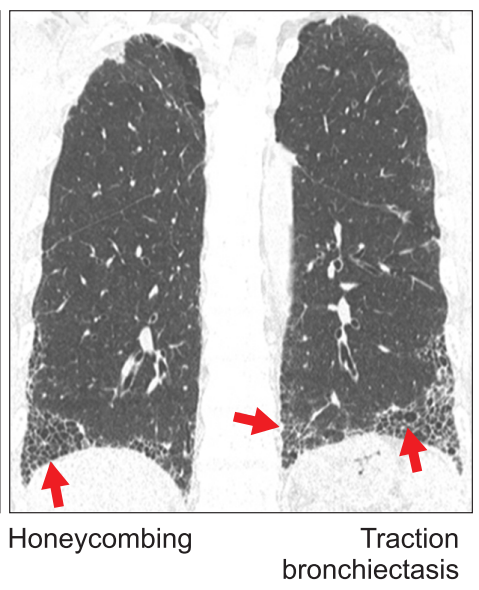

bronchiectasis

Figure 1. High resolution computed tomography images demonstrating usual interstitial pneumonia (arrows) (A) and possible usual interstitial pneumonia (arrows) (B) (Courtesy from Ulsan College of Medicine, Asan Medical Center, Internal Medicine, Prof. Song JW).
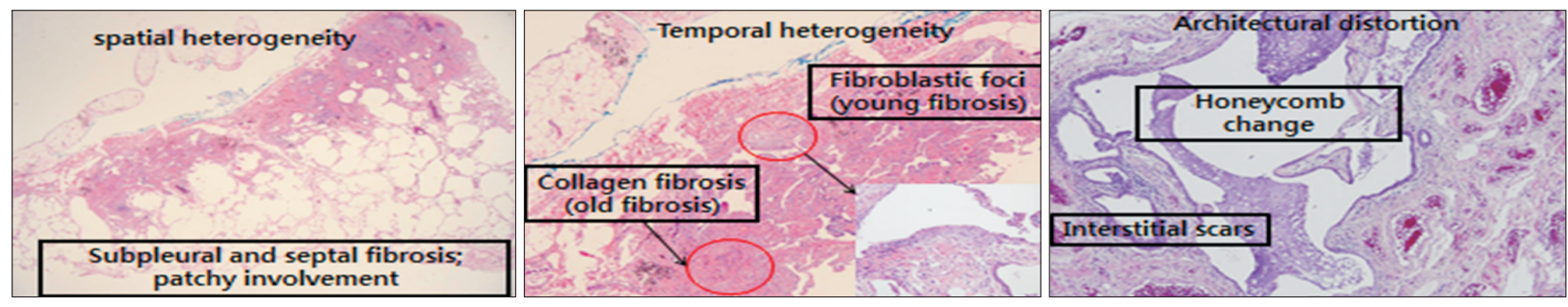

Figure 2. Surgical lung biopsy specimen demonstrating usual interstitial pneumonia pattern (Courtesy from Yonsei University, College of Pathology Prof. Sim HS).

- Absence of features against the diagnosis of UIP suggesting an alternative diagnosis

Or

- Honeycomb change only

\section{(3) Possible UIP pattern}

- Patchy or diffuse involvement of the lung parenchyma by fibrosis, \pm interstitial inflammation

- Absence of other criteria for UIP

- Absence of features against the diagnosis of UIP suggesting an alternative diagnosis

\section{Diagnosis of IPF}

IPF is associated with the histopathological and/or HRCT pattern of UIP ${ }^{1}$.

The diagnosis of IPF requires:

- Exclusion of other known causes of interstitial lung disease (ILD)

- The presence of a UIP pattern on HRCT in patients who have not been subjected to surgical lung biopsy

- Specific combination of HRCT and surgical lung biopsy pattern in patients subjected to surgical lung biopsy. 
Table 1. Comparison of recommendations in the 2015 and 2011 idiopathic pulmonary fibrosis guidelines (modified)

\begin{tabular}{|lll|}
\hline \multicolumn{1}{|c|}{ Recommendation } & \multicolumn{1}{c|}{ 2015 Guideline } & \multicolumn{1}{c|}{ 2011 Guideline } \\
\hline Strong against use & $\begin{array}{l}\text { Anticoagulation (warfarin), imatinib, selective TKI against } \\
\text { PDGF receptors } \\
\text { Combination PL+AZA+NAC } \\
\text { Selective ERA (ambrisentan) }\end{array}$ & Dual ERAs (macitentan, bosentan) \\
Conditional against use & $\begin{array}{l}\text { Phosphodiesterase-5 inhibitor (sildenafil) } \\
\text { Dual ERAs (macitentan, bosentan) }\end{array}$ & $\begin{array}{l}\text { Anticoagulation (warfarin), } \\
\text { Combination PL+AZA+NAC } \\
\text { Pirfenidone } \\
\text { NAC monotherapy } \\
\text { Anti-PH therapy }\end{array}$ \\
\hline Conditional use & Nintedanib, a TKI targets multiple TKs & Antiacid therapy \\
& including VEGF, FGF, and PDGF receptors & \\
Pirfenidone & Antiacid therapy & NA \\
\hline
\end{tabular}

TKI: tyrosine kinase inhibitor; PDGF: platelet derived growth factor; PL: prednisone; AZA: azathioprine; NAC: N-acetylcysteine; ERA: endothelin receptor antagonist; PH: pulmonary hypertension; TK: tyrosine kinase; VEGF: vascular endothelial growth factor; FGF: fibroblast growth factor; LTX: lung transplantation; NA: not available.

The accuracy of the diagnosis of IPF increased with multidisciplinary discussions between pulmonologists, radiologists, and pathologists who have experience at diagnosing $\operatorname{ILD}^{65}$.

\section{Treatment of Idiopathic Pulmonary Fibrosis}

The treatment of IPF was described according to an official ATS/ERS/JRS/ALAT clinical practice guideline: treatment of idiopathic pulmonary fibrosis: an update of the 2011 clinical practice guideline (Table 1$)^{3}$.

For the treatment of IPF, there is a strong recommendation against the use of the following: anticoagulation (warfarin), imatinib (a selective tyrosine kinase inhibitor against PDGF receptors), combination prednisone, azathioprine, and $\mathrm{N}$ acetylcysteine, and selective endothelin receptor antagonist (ambrisentan). Furthermore, for the treatment of IPF, there is a conditional recommendation against the use of the following agents: phosphodiesterase-5 inhibitor (sildenafil) and dual endothelin receptor antagonists (macitentan, bosentan). NAcetylcysteine monotherapy and antacid therapy were left unchanged from the 2011 guideline. However, for the treatment of IPF, there is a conditional recommendation for the use of the following agents: nintedanib (tyrosine kinase inhibitor that targets multiple tyrosine kinases) and pirfenidone.

According to the 2015 international guideline, The Korean ILD guideline group selected PICOs concerning pirfenidone, nintedanib, and lung transplantation, for the treatment of IPF, from systemic literature review.

\section{PICO for the treatment of patients with IPF}

PICO 1: Does pirfenidone reduce the decrease in forced vital capacity (FVC) in patients with IPF?

PICO 2: Does nintedanib reduce the decrease in FVC in patients with IPF?

PICO 3: Does lung transplantation improve the survival in patients with IPF compared with medical treatment?

2. Summary of the recommendations for the treatment of patients with IPF

- We suggest that clinicians use pirfenidone in patients with IPF to reduce the decrease in FVC (strong recommendation, high confidence in estimates of effect).

- We suggest that clinicians use nintedanib in patients with IPF to reduce the decrease in FVC (strong recommendation, high confidence in estimates of effect).

- We suggest lung transplantation in patients with IPF at appropriate times to improve survival (strong recommendation, moderate confidence in estimates of effect).

In collaboration with Dr. Hyun Jung Kim (Korea University), a clinical guideline special scientist, we designed a search strategy using medical subject heading keywords and text words (see online supplement), limited to human studies, nonindexed citations, and articles either in English or in any language with English abstracts. Literature searches for pirfenidone, nintedanib, and lung transplantation clinical trials, published up to September 2016, were carried out on four databases (MEDLINE, EMBASE, COCHRANE library, and KoreaMed). 


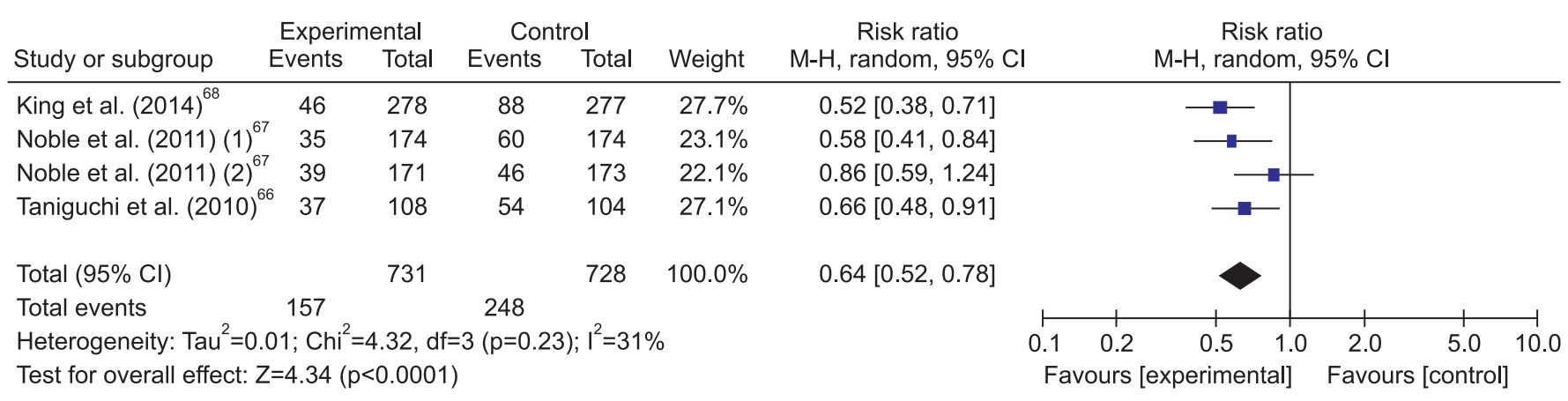

Figure 3. Forest plot of the risk difference of percentage of study population with forced vital capacity decreased by more than $10 \%$. CI: confidence interval.

\begin{tabular}{|c|c|c|c|c|c|c|}
\hline \multirow{2}{*}{$\begin{array}{l}\text { Study or subgroup Std. } \\
\text { Richeldi et al. }(2011)^{69}\end{array}$} & Mean difference & \multirow{2}{*}{$\frac{S E}{56}$} & \multirow{2}{*}{$\begin{array}{r}\text { Weight } \\
8.7 \%\end{array}$} & \multirow{2}{*}{$\begin{array}{r}\text { Std. Mean difference } \\
\text { IV, Fixed, 95\% Cl }\end{array}$} & \multicolumn{2}{|c|}{$\begin{array}{l}\text { Std. Mean difference } \\
\text { IV, Fixed, } 95 \% \mathrm{Cl}\end{array}$} \\
\hline & -130 & & & & & \\
\hline Richeldi et al. (2014) (1) $)^{70}$ & -125 & 24 & $47.5 \%$ & $-125.00[-172.04,-77.96]$ & & \\
\hline Richeldi et al. (2014) (2) & -94 & 25 & $43.8 \%$ & $-94.00[-143.00,-45.00]$ & & \\
\hline \multicolumn{5}{|c|}{ Heterogeneity: $C h i^{2}=0.92, d f=2(p=0.63) ; I^{2}=0 \%$} & & \\
\hline \multicolumn{5}{|c|}{ Test for overall effect: $Z=6.76(p<0.00001)$} & $\begin{array}{c}-200-100 \\
\text { Favours [nintedanib] }\end{array}$ & $\begin{array}{l}100200 \\
\text { Favours [placebo] }\end{array}$ \\
\hline
\end{tabular}

Figure 4. Difference in annual forced vital capacity decline rate between nintedanib and placebo groups. CI: confidence interval.

\section{Pirfenidone: PICO1 summary}

In order to develop Korean Interstitial Lung Disease guideline, we performed a systematic review and meta-analysis on the treatment efficacy of pirfenidone $(1,800 \mathrm{mg}$ or 2,403 $\mathrm{mg}$ daily). The end-point was the number of patients who had a decrease in vital capacity (VC) or FVC with more than $10 \%$ decline (Figure 3).

A total of 1,092 articles, after removal of duplicates, were screened. Among them, 31 articles were eligible for the fulltext review, which revealed three studies (Japan study, CAPACITY, and ASCEND trials) that were finally included for qualitative and quantitative analyses.

Japan study ${ }^{66}$ was a phase-3, randomized controlled, multicenter prospective study conducted for 52 weeks. The primary endpoint of this study was change in $\mathrm{VC}$. The mean changes in $\mathrm{VC}$ were $-0.16 \mathrm{~L}$ and $-0.09 \mathrm{~L}$ in the placebo and pirfenidone groups, respectively. The numbers of patients with a decrease in VC of $10 \%$ or more were 54/104 (51.9\%) and 37/108 (34.2\%) in the placebo and pirfenidone groups, respectively.

CAPACITY $^{67}$ was a phase-3, two replicated, 72-week, randomized double blind, multicenter trial. Since CAPACITY consisted of two separate trials (studies 004 and 006), overall, four trials were actually analyzed in this review. The primary endpoint was change in FVC at week 72. In study 004, mean
FVC change at week 72 was $-8.0 \%$ (standard deviation [SD], 16.5 ) in the pirfenidone $2,403 \mathrm{mg} /$ day group and $-12.4 \%$ (18.5) in the placebo group (difference, $4.4 \%$; $95 \%$ confidence interval [CI], 0.7-9.1); 35 of 174 (20\%) versus 60 of 174 patients (35\%), respectively, had a decline of at least $10 \%$ (difference, 4.4\%; 95\% CI, 0.7-9.1). In study 006, mean change in FVC at week 72 was $-9.0 \%(\mathrm{SD}, 19.6)$ in the pirfenidone group and $-9.6 \%$ (19.1) in the placebo group, and the difference between groups in predicted FVC change at week 72 was not significant $(0.6 \%,-3.5$ to 4.7$)$.

ASCEND trial ${ }^{68}$ was a phase-3, randomized controlled, multicenter prospective study conducted for 52 weeks. The primary end point was the change in FVC or death at week 52. FVC decline at week 52 was $-280 \mathrm{~mL}$ in the placebo and -164 $\mathrm{mL}$ in the pirfenidone group (absolute difference, $116 \mathrm{~mL}$; relative difference, $41.5 \%$; $\mathrm{p}<0.001$ ). The number of patients who had a decrease in FVC of $10 \%$ or more was 88/277 (31.8\%) in placebo, and 46/278 (16.5\%) in pirfenidone group.

Risk of bias from the three studies was low. Quality of the evidence was moderate.

In conclusion, we found four trials in three studies that prospectively analyzed the efficacy of pirfenidone in terms of the lung function (FVC). This review revealed that pirfenidone delayed the disease progression by retarding the rate of FVC decline. 


\begin{tabular}{|c|c|c|c|c|c|}
\hline Author & & OR $(95 \% \mathrm{Cl})$ & $\begin{array}{l}\text { Events, } \\
\text { treatment }\end{array}$ & $\begin{array}{l}\text { Events, } \\
\text { control }\end{array}$ & $\begin{array}{r}\% \\
\text { Weight }\end{array}$ \\
\hline Thabut et al. (2003) & $+\frac{1}{i}$ & $25.67(4.53,145.49)$ & $22 / 28$ & $2 / 16$ & 44.54 \\
\hline Riddell et al. $(2013)^{71}$ & $\div$ & $25.50(5.62,115.77)$ & $27 / 30$ & $6 / 23$ & 55.46 \\
\hline Overall (I-squared $=0.0 \%, p=0.996)$ & $\frac{1}{1}$ & $25.57(8.17,80.02)$ & $49 / 58$ & $8 / 39$ & 100.00 \\
\hline
\end{tabular}

Figure 5. Difference in survival between lung transplantation and placebo groups. OR: odds ratio; CI: confidence interval.

\section{Nintedanib: PICO2 summary}

A systematic review and meta-analysis, on the treatment efficacy of nintedanib ( $150 \mathrm{mg}$, twice daily) was conducted in order to evaluate the annual FVC decline rate by nintedanib in patients with IPF (Figure 4). Among 407 articles, three trials from two studies (INPULSIS and TOMORROW) ${ }^{69,70}$ were eligible for our review. In the pooled analysis, the difference in annual rates of FVC decline between the two groups was $-111.9 \mathrm{~mL}$ (95\% CI, -144.3 to $-79.5 ; \mathrm{p}<0.001)$, which indicated that nintedanib slowed the rate of FVC decline. In addition, the number of patients with over $10 \%$ or $200 \mathrm{~mL}$ reduction in FVC from the baseline was lower in nintedanib group (risk ratio, 0.59; $\mathrm{p}<0.001$ ). Risk of bias from both studies was low. However, both studies had high withdrawal rate, and the quality of the evidence was moderate. In conclusion, nintedanib could delay disease progression by retarding the rate of FVC decline.

\section{Lung transplantation: PICO3 summary}

Given the progressive and incurable nature of IPF, lung transplantation is commonly considered in patients with moderate to severe disease. Due to the lack of randomized controlled trial evidence to guide this recommendation, we considered observational studies which assessed the survival of patients with IPF, with or without lung transplantation waiting cohort (Figure 5).

We selected two articles and one abstract through extensive review of literature.

Riddell et al. ${ }^{71}$ showed that for those patients on the lung transplant waiting list, who did not receive a transplant, survival was unfortunately poor $(75 \%$ at 6 months, $30 \%$ at 12 months, and $15 \%$ at 18 months). However, following transplantation, all-age survival was $96.6 \%$ at 1 year, $90.1 \%$ at 2 years, and $78.9 \%$ at 5 years. The 5 -year survival of those transplanted over the age of 65 was $88.9 \%(n=9)^{72}$.

Thabut et al. ${ }^{72}$ reported that 28 patients underwent lung transplantation (27 single and 1 double), 16 patients died while waiting, and two patients remained on the active waiting list. Survival after lung transplantation was $79.4 \%$ at 1 year, $63.5 \%$ at 2 years, and $39.0 \%$ at 5 years. The multivariable analysis showed that lung transplantation reduced the risk of death by $75 \%$ (95\% CI, $8 \%-86 \%$; $\mathrm{p}=0.03$ ) after adjustment for potential confounding variables ${ }^{72}$.

Meta-analysis showed that lung transplantation improved survival 26 times compared to not having received transplantation in patient with IPF.

\section{Prognosis of Idiopathic Pulmonary Fibrosis}

\section{Natural history of IPF}

IPF is a chronic progressive pulmonary disease with an average life expectancy of about 3 years $^{73}$. Most causes of death in IPF are due to IPF itself (progression into respiratory failure $)^{6}$. Natural history of IPF is very diverse, and individual disease course is difficult to predict. There are also numerous fibrotic lung diseases which share clinical features with IPF, but are clearly differentiated pathologically and show different prognosis. Therefore, clear diagnosis of IPF via multidisciplinary integration of clinical, radiological, and useful histologic material is necessary. Moreover, even after definitive diagnosis, there is individual variability in the disease course. Thus, it is very difficult for clinicians to predict the future prognosis in individual patients at the time of diagnosis.

Rapid deterioration can occur at any time in the disease course of IPF and it can be attributed to known causes such as infections or unknown; and, it is defined as "acute exacerbation." Approximately $5 \%-10 \%$ of patients experience acute exacerbations each year ${ }^{1}$, and it is the most important cause of hospitalization and death in IPF patients ${ }^{74}$. A domestic prospective study that analyzed 461 IPF patients showed a significantly shorter survival (15.5 months vs. 60.6 months postdiagnosis) and lower 5 -year survival ( $18.4 \%$ vs. $50 \%$ ) in those who experienced acute exacerbations ${ }^{75}$. A retrospective analysis of IPF patients who were included as control group in a large 2 or 3 phase clinical studies reported that the average decrease in FVC in IPF reached 0.16 to $0.28 \mathrm{~L}_{\text {per year }}^{76}$.

A number of studies were conducted to confirm the disease characteristics useful for prognosis prediction in IPF. Since the measurement at baseline alone was insufficient to predict the risk of progression, the degree of change in important clinical variables in IPF, including pulmonary function, exercise test, 
and chest computed tomography (CT), were also studied for their efficacy ${ }^{77}$.

\section{Prognostic index and prognostic model}

Because predict the prognosis with a single variable in IPF is almost impossible ${ }^{78-80}$, clinical prediction models, with these individual variables mixed in, has been proposed ${ }^{81-83}$.

\section{1) Clinical prognostic index}

(1) Comorbidity: Various comorbidities are known to be associated with poor prognosis in IPF patients, including pulmonary hypertension $^{84}$, accompanying emphysema ${ }^{85}$, etc. Gastroesophageal reflux disease (GERD) is accompanied in up to $87 \%$ in IPF patients, microscopic aspiration, from chronic GERD repeatedly induces lung injury and can contribute to the exacerbation of $\operatorname{IPF}^{19}$.

(2) Age: Several studies reported that older patients show a worse prognosis ${ }^{1,78}$, but some studies reported similar prognosis even in those less than 50 years old ${ }^{86}$.

(3) Sex: Although there are various reports about the influence of sex on IPF deaths ${ }^{1,78}$, in one study including 215 patients, women showed remarkably longer survival compared to men even after adjusting for age, smoking history, diffusing capacity, and maximum desaturation area ${ }^{46}$.

(4) Smoking history: Smoking is associated with both increased and decreased mortality in IPF patients ${ }^{38,79}$.

(5) Body mass index: A low body mass index can be an index of poor nutrition and increased energy expenditure at both baseline and during exercise. It shows a significant correlation with lower survival ${ }^{87}$.

(6) Severity of dyspnea: Degree of dyspnea at diagnosis and dyspnea progression according to the time period seemed to be related to mortality ${ }^{88}$.

(7) Oxygen therapy: Irrespective of $\mathrm{VC}$ or the 6-minute walking distance (6MWD), the higher the oxygen demand to maintain percutaneous oxygen saturation at rest in over $96 \%$ of IPF patients, the higher the mortality rate ${ }^{89}$.

(8) Baseline pulmonary function: The most common pulmonary function indices showing correlation with prognosis are FVC, total lung capacity (TLC), and diffusing capacity for carbon monoxide (DLCO) $)^{90}$.

(9) Decline in pulmonary function: Changes in pulmonary function show superior predictive power than baseline pulmonary function. Decrease in FVC at 6 or 12 months reliably predicted death ${ }^{90,91}$. Predictive accuracy is higher when using FVC decreases of over $10 \%$ as significant threshold rather than the absolute change in $\mathrm{FVC}^{92}$. The decrease in DLCO is also associated with increased mortality ${ }^{93}$, and $\left[\mathrm{P}(\mathrm{A}-\mathrm{a}) \mathrm{O}_{2}\right]$ decrease $>15 \mathrm{~mm} \mathrm{Hg}$ at 12 months is also related to mortality $^{94}$.

(10) The 6MWD: The 6MWD at diagnosis and changes in $6 \mathrm{MWD}$ can predict mortality. In one study, baseline 6MWD below $250 \mathrm{~m}$ and decrease in 6MWD over $50 \mathrm{~m}$ at week 24 , was reported as an independent predictor of death. However, the predictive value of the 6MWD is limited due to lack of appropriate standardization ${ }^{95}$.

(11) Acute exacerbation: Acute exacerbation of IPF is related to higher mortality ${ }^{96}$.

\section{2) Radiological, histopathological, and serum predic- tors}

Chest HRCT is a standard imaging test in the evaluation of IPF, providing diagnostic and predictive information. Fibrosis and honeycomb extent observed in chest HRCT have shown correlation with FVC and DLCO\%, thus predicting mortality $^{97}$. The automated quantified volumes of lung parenchymal abnormalities observed in chest HRCT can also predict mortality $^{98}$. In terms of histopathologic predictors, increased fibroblastic foci showed increased mortality ${ }^{99}$. Some proteins in circulating blood have been reported as associated with survival in $\mathrm{IPF}^{1,78}$, but the role as a biomarker of prognosis prediction has not been fully verified. Five proteins (matrix metalloproteinase 7 , intercellular adhesion molecule 1 , interleukin-8, vascular cell adhesion molecule 1, and S100A12) were studied to confirm survival prediction power by integration of these serum predictors and physiological variables together, resulting in its efficacy regardless of age, sex, and even baseline lung function ${ }^{100}$.

\section{3) Composite risk indices}

Disease progression and death in IPF is difficult to predict due to the high variability of the disease itself. Therefore, a number of risk-related indices have been developed. Although a composite clinical-radiologic-physiologic score system was developed ${ }^{101}$, it could not be widely used because of the many variables which are not routinely measured.

In addition, Mura et al. ${ }^{102}$ developed a risk standardization tool to predict survival and rapid progression. Medical Research Council Dyspnea Score $>3,6 \mathrm{MWD}<72 \%$ predicted, and composite physiologic index $>41$ were independent predictors of 3-year survival. And with these, the risk stratification score (ROSE) was established.

De Bois et al. ${ }^{83}$ developed a scoring system using independent predictors of mortality from two clinical research data ${ }^{103}$. A simplified model of this includes age, hospitalization due to respiratory causes, $\mathrm{FVC} \%$ predicted, and changes in $\mathrm{FVC} \%$ predicted at week 24 . The predictive ability for 1-year survival was significantly improved when baseline 6MWD and the change in 6MWD at week 24 were added together ${ }^{95}$.

As a simple but important prognostic model, multidimensional GAP indicator (gender $[\mathrm{G}]$, age $[\mathrm{A}]$, and two physiologic factors: FVC and DLCO [P]) was developed and is in use $\mathrm{e}^{103}$. The GAP prediction model was verified for prediction accuracy of actual mortality even in Japan and Korea ${ }^{104}$. 
3. Prognostic judgment and assessment recommendations in IPF: 2013 NICE guideline

- Evaluation of the rate of initial clinical deterioration with serial pulmonary function test (spirometry test and DLCO) to predict the subsequent clinical course and prognosis of each patient: at the time of diagnosis, 6 months, and 12 months after initial diagnosis.

- If the clinical manifestation deteriorates rapidly, repeat test with shorter intervals is necessary.

- Do not use the 6MWD result at diagnosis for prognosis prediction.

- Respiratory specialists or specialized ILD nursing team should provide accurate and clear information including test results, clinical diagnosis, and management.

- When interviewing IPF patient at the time of diagnosis, it should include discussion about the expected prognosis in a careful manner. At this time, disease severity, average life expectancy, the variety of disease course, and the range of expected survival, as well as information on the selectable treatment methods should be provided.

\section{Acute Exacerbation of Idiopathic Pulmonary Fibrosis}

\section{Definition of acute exacerbation of IPF}

According to the results of recent studies, the natural course of IPF is not constant ${ }^{105}$. Some patients experience acute worsening with a gradual decline in pulmonary function, which are caused by infection, heart failure, pulmonary embolism, and pneumothorax. However, there are cases where the cause is unknown despite precise examination ${ }^{106}$. Acute exacerbation is defined as acute and severe respiratory deterioration associated with new bilateral lung infiltration in IPF patients. Acute exacerbation can occur in patients with nonspecific interstitial pneumonia, hypersensitivity pneumonitis, and connective tissue disease related interstitial pneumonia ${ }^{107}$.

\section{Clinical manifestations of acute exacerbation}

The main symptom is the deterioration of dyspnea within one month. In some patients, fever, cough, increased sputum, elevated C-reactive protein, hypoxemia, and neutrophilia in bronchoalveolar lavage fluid can be seen ${ }^{108}$. Diffuse bilateral pulmonary infiltration is shown on chest radiography, diffuse alveolar damage, multiple fibroblastic foci, or organizing pneumonia can be seen in lung biopsy specimen.

\section{Clinical impact of acute exacerbation}

Acute exacerbation has a fatal impact on the prognosis of the patient. The median survival time after acute exacerbation was 22 days to 4.2 months, and the hospital mortality rate was reported as $27 \%-96 \%{ }^{106}$. Also, IPF patients who experienced acute exacerbation (median survival time, 15.5 months; 5-year survival, $18.4 \%$ ) have worse outcome than others (median survival time, 60.6 months; 5-year survival, 50.0\%) ${ }^{75}$.

\section{Incidence and risk factors of acute exacerbation}

The annual incidence of acute exacerbation is known approximately as $5 \%$ to $10 \%$, but variable in many studies $(18 \%$ to $61 \%)^{105,106}$.

Although the risk factors of acute exacerbation are not well known, several studies have shown that pulmonary function (FVC, diffusion capacity, TLC), the severity of dyspnea (modified medical research council scale $\geq 2$ ), the fibrosis extent on chest CT, FVC decline at six months, are associated with acute exacerbation ${ }^{75,96,105,109}$. Additionally, bronchoscopy, bronchoalveolar lavage, thoracoscopic lung biopsy, and pulmonary

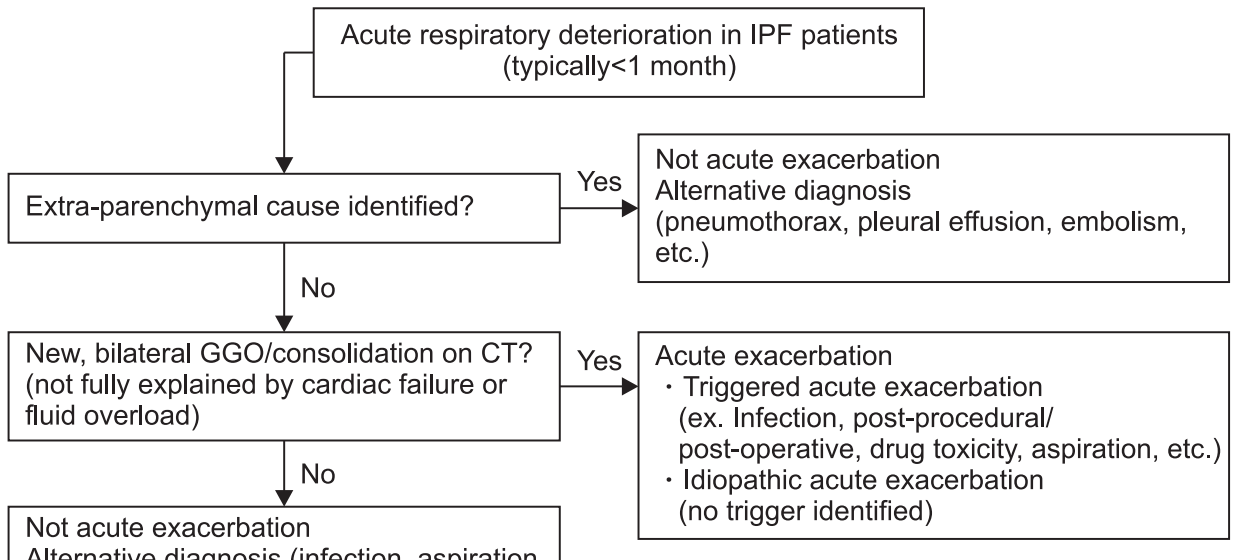

Alternative diagnosis (infection, aspiration, drug toxicity, cardiac failure, etc.)
Figure 6. Diagnostic algorism of acute respiratory deterioration in idiopathic pulmonary fibrosis patients. IPF: idiopathic pulmonary fibrosis; GGO: ground glass opacity; CT: computed tomography. 
resection of lung cancer could result in acute exacerbation in patients with $\mathrm{IPF}^{75,106}$.

\section{Etiologies of acute exacerbation}

The cause of acute exacerbations is not well known, but some studies have suggested possibility of deterioration of underlying disease characterized by acute lung injury ${ }^{110,111}$. Also, viral infection, aspiration, and air pollution might contribute to the development of acute exacerbation in some patients ${ }^{112-114}$.

\section{Diagnostic criteria of acute exacerbation}

According to international guidelines on the acute exacerbation of IPF in 2007, acute exacerbation was defined as (1) deterioration of dyspnea within 30 days, (2) new bilateral pulmonary infiltration on chest HRCT, and (3) exclusion of known causes of acute lung injury (i.e., infection, heart failure, and pulmonary embolism) even with detailed examinations such as bronchial aspiration or bronchoalveolar lavage analysis. If acute exacerbation is suspected, but all of the above conditions are not met, these conditions are defined as suspected acute exacerbation $^{106}$.

Revised diagnostic criteria of acute exacerbation were published in $2016^{114}$. The revised definition is an acute, severe respiratory deterioration with new bilateral pulmonary infiltration, (1) previous or concurrent diagnosis of IPF, (2) development or acute worsening of dyspnea typically less than 1-month duration, (3) chest CT with new bilateral groundglass opacity and/or consolidation on a background pattern consistent with the UIP pattern, and 4) deterioration not fully explained by heart failure or fluid overload. Similarly, events that are clinically considered acute exacerbation but fail to meet all four diagnostic criteria are termed as suspected acute exacerbations.

In previous diagnostic criteria, acute exacerbation was diagnosed when the cause of acute lung injury such as infection or aspiration was excluded (idiopathic). However, in the revised edition, bilateral pulmonary infiltration except pulmonary edema was classified as acute exacerbation regardless of etiology. Acute exacerbations are further categorized as triggered acute exacerbation (e.g., infection, aspiration, surgery, or drug) or idiopathic acute exacerbation (no trigger identified) (Figure 6). In addition, although the period of occurrence was limited to (the development or deterioration of dyspnea within one month) in previous edition, revised criteria was changed to the time interval from one month to (typically less than 1 month), which makes the inclusion of suspected cases to be acute exacerbation, which was not previously classified owing to a period problem.

\section{Prevention and treatment of acute exacerbation}

To date, the treatment of acute exacerbation has been largely lacking in evidence, only based on case reports or retrospective cohort studies. The basis of acute exacerbation treatment is supportive treatment for acute lung injury. Although there is insufficient evidence for drug treatment, giving priority to high dose steroid therapy ${ }^{105}$, cyclosporin A, or warfarin, is recommended; however, afterwards, warfarin has been shown to increase the mortality in patients with $\mathrm{IPF}^{115}$. Although these are not listed in the recommendation, in some reports, immunosuppresants such as cyclophosphamide or tacrolimus, and polymyxin B immobilized fiber column hemoperfusion were reported to be helpful; prospective studies are needed to confirm these results. Recently, pirfenidone and nintedanib, which have been shown to be effective in slowing the progress of IPF, have also been shown to reduce incidence of acute exacerbations, in phase II trials. In some patients, stoppage of exposure to air pollution, vaccination, and treatment of GER might be helpful in preventing acute exacerbation. Considering the high mortality, mechanical ventilation is not recommended for severe respiratory failure in patients with acute exacerbation, unless lung transplantation is not being considered.

\section{Authors' Contributions}

Conceptualization: Park MS. Methodology: Kim YH, Park JS, Park J. Formal analysis: Lee SH, Park MS. Data curation: Lee SH. Writing - original draft preparation: Lee SH, Yeo Y, Kim TH, Lee HL, Lee JH, Park YB, Park JS, Kim YH, Song JW, Jhun BW, Kim HJ, Park J, Park MS. Writing - review and editing: Uh ST, Kim WH, Kim DS, Park MS. Approval of final manuscript: all authors.

\section{Conflicts of Interest}

No potential conflict of interest relevant to this article was reported.

\section{References}

1. Raghu G, Collard HR, Egan JJ, Martinez FJ, Behr J, Brown KK, et al. An official ATS/ERS/JRS/ALAT statement: idiopathic pulmonary fibrosis: evidence-based guidelines for diagnosis and management. Am J Respir Crit Care Med 2011;183:788824.

2. American Thoracic Society; European Respiratory Society. American Thoracic Society/European Respiratory Society International Multidisciplinary Consensus Classification of 
the Idiopathic Interstitial Pneumonias. This joint statement of the American Thoracic Society (ATS), and the European Respiratory Society (ERS) was adopted by the ATS board of directors, June 2001 and by the ERS Executive Committee, June 2001. Am J Respir Crit Care Med 2002;165:277-304.

3. Raghu G, Rochwerg B, Zhang Y, Garcia CA, Azuma A, Behr J, et al. An official ATS/ERS/JRS/ALAT clinical practice guideline: treatment of idiopathic pulmonary fibrosis. An update of the 2011 clinical practice guideline. Am J Respir Crit Care Med 2015;192:e3-19.

4. Scientific Committee of the Korean Academy of Tuberculosis and Respiratory Diseases. 2008 National survey of idiopathic interstitial pneumonia in Korea. Tuberc Respir Dis 2009;66:141-51.

5. Coultas DB, Zumwalt RE, Black WC, Sobonya RE. The epidemiology of interstitial lung diseases. Am J Respir Crit Care Med 1994;150:967-72.

6. Fernandez Perez ER, Daniels CE, Schroeder DR, St Sauver J, Hartman TE, Bartholmai BJ, et al. Incidence, prevalence, and clinical course of idiopathic pulmonary fibrosis: a population-based study. Chest 2010;137:129-37.

7. Lai CC, Wang CY, Lu HM, Chen L, Teng NC, Yan YH, et al. Idiopathic pulmonary fibrosis in Taiwan: a populationbased study. Respir Med 2012;106:1566-74.

8. Raghu G, Weycker D, Edelsberg J, Bradford WZ, Oster G. Incidence and prevalence of idiopathic pulmonary fibrosis. Am J Respir Crit Care Med 2006;174:810-6.

9. Scott J, Johnston I, Britton J. What causes cryptogenic fibrosing alveolitis? A case-control study of environmental exposure to dust. BMJ 1990;301:1015-7.

10. von Plessen C, Grinde O, Gulsvik A. Incidence and prevalence of cryptogenic fibrosing alveolitis in a Norwegian community. Respir Med 2003;97:428-35.

11. Karakatsani A, Papakosta D, Rapti A, Antoniou KM, Dimadi M, Markopoulou A, et al. Epidemiology of interstitial lung diseases in Greece. Respir Med 2009;103:1122-9.

12. Gjonbrataj J, Choi WI, Bahn YE, Rho BH, Lee JJ, Lee CW. Incidence of idiopathic pulmonary fibrosis in Korea based on the 2011 ATS/ERS/JRS/ALAT statement. Int J Tuberc Lung Dis 2015;19:742-6.

13. Gribbin J, Hubbard RB, Le Jeune I, Smith CJ, West J, Tata LJ. Incidence and mortality of idiopathic pulmonary fibrosis and sarcoidosis in the UK. Thorax 2006;61:980-5.

14. Iwai K, Mori T, Yamada N, Yamaguchi M, Hosoda Y. Idiopathic pulmonary fibrosis. Epidemiologic approaches to occupational exposure. Am J Respir Crit Care Med 1994;150: 670-5.

15. Baumgartner KB, Samet JM, Stidley CA, Colby TV, Waldron JA. Cigarette smoking: a risk factor for idiopathic pulmonary fibrosis. Am J Respir Crit Care Med 1997;155:242-8.

16. Hubbard R, Lewis S, Richards K, Johnston I, Britton J. Occupational exposure to metal or wood dust and aetiology of cryptogenic fibrosing alveolitis. Lancet 1996;347:284-9.
17. Lee SH, Kim DS, Kim YW, Chung MP, Uh ST, Park CS, et al. Association between occupational dust exposure and prognosis of idiopathic pulmonary fibrosis: a Korean national survey. Chest 2015;147:465-74.

18. Tobin RW, Pope CE 2nd, Pellegrini CA, Emond MJ, Sillery J, Raghu G. Increased prevalence of gastroesophageal reflux in patients with idiopathic pulmonary fibrosis. Am J Respir Crit Care Med 1998;158:1804-8.

19. Raghu G, Freudenberger TD, Yang S, Curtis JR, Spada C, Hayes J, et al. High prevalence of abnormal acid gastrooesophageal reflux in idiopathic pulmonary fibrosis. Eur Respir J 2006;27:136-42.

20. Enomoto T, Usuki J, Azuma A, Nakagawa T, Kudoh S. Diabetes mellitus may increase risk for idiopathic pulmonary fibrosis. Chest 2003;123:2007-11.

21. Tang YW, Johnson JE, Browning PJ, Cruz-Gervis RA, Davis A, Graham BS, et al. Herpesvirus DNA is consistently detected in lungs of patients with idiopathic pulmonary fibrosis. J Clin Microbiol 2003;41:2633-40.

22. Kelly BG, Lok SS, Hasleton PS, Egan JJ, Stewart JP. A rearranged form of Epstein-Barr virus DNA is associated with idiopathic pulmonary fibrosis. Am J Respir Crit Care Med 2002;166:510-3.

23. Ueda T, Ohta K, Suzuki N, Yamaguchi M, Hirai K, Horiuchi $\mathrm{T}$, et al. Idiopathic pulmonary fibrosis and high prevalence of serum antibodies to hepatitis C virus. Am Rev Respir Dis 1992;146:266-8.

24. Renzoni E, Srihari V, Sestini P. Pathogenesis of idiopathic pulmonary fibrosis: review of recent findings. F1000Prime Rep 2014;6:69.

25. Selman M, King TE, Pardo A; American Thoracic Society; European Respiratory Society; American College of Chest Physicians. Idiopathic pulmonary fibrosis: prevailing and evolving hypotheses about its pathogenesis and implications for therapy. Ann Intern Med 2001;134:136-51.

26. Khalil N, O'Connor RN, Flanders KC, Unruh H. TGF-beta 1, but not TGF-beta 2 or TGF-beta 3, is differentially present in epithelial cells of advanced pulmonary fibrosis: an immunohistochemical study. Am J Respir Cell Mol Biol 1996;14:1318.

27. Zhang L, Wang Y, Pandupuspitasari NS, Wu G, Xiang X, Gong Q, et al. Endoplasmic reticulum stress, a new wrestler, in the pathogenesis of idiopathic pulmonary fibrosis. Am J Transl Res 2017;9:722-35.

28. Armanios MY, Chen JJ, Cogan JD, Alder JK, Ingersoll RG, Markin C, et al. Telomerase mutations in families with idiopathic pulmonary fibrosis. N Engl J Med 2007;356:1317-26.

29. Alder JK, Chen JJ, Lancaster L, Danoff S, Su SC, Cogan JD, et al. Short telomeres are a risk factor for idiopathic pulmonary fibrosis. Proc Natl Acad Sci U S A 2008;105:13051-6.

30. Seibold MA, Wise AL, Speer MC, Steele MP, Brown KK, Loyd JE, et al. A common MUC5B promoter polymorphism and pulmonary fibrosis. N Engl J Med 2011;364:1503-12. 
31. Wolters PJ, Collard HR, Jones KD. Pathogenesis of idiopathic pulmonary fibrosis. Annu Rev Pathol 2014;9:157-79.

32. Munger JS, Huang X, Kawakatsu H, Griffiths MJ, Dalton SL, $\mathrm{Wu}$ J, et al. The integrin alpha v beta 6 binds and activates latent TGF beta 1: a mechanism for regulating pulmonary inflammation and fibrosis. Cell 1999;96:319-28.

33. Willis BC, duBois RM, Borok Z. Epithelial origin of myofibroblasts during fibrosis in the lung. Proc Am Thorac Soc 2006; 3:377-82.

34. Strieter RM, Keeley EC, Hughes MA, Burdick MD, Mehrad B. The role of circulating mesenchymal progenitor cells (fibrocytes) in the pathogenesis of pulmonary fibrosis. J Leukoc Biol 2009;86:1111-8.

35. Pardo A, Cabrera S, Maldonado M, Selman M. Role of matrix metalloproteinases in the pathogenesis of idiopathic pulmonary fibrosis. Respir Res 2016;17:23.

36. Navaratnam V, Fogarty AW, McKeever T, Thompson N, Jenkins G, Johnson SR, et al. Presence of a prothrombotic state in people with idiopathic pulmonary fibrosis: a populationbased case-control study. Thorax 2014;69:207-15.

37. Yang IV, Schwartz DA. Epigenetic control of gene expression in the lung. Am J Respir Crit Care Med 2011;183:1295-301.

38. Bellaye PS, Kolb M. Why do patients get idiopathic pulmonary fibrosis? Current concepts in the pathogenesis of pulmonary fibrosis. BMC Med 2015;13:176.

39. Fell CD, Martinez FJ, Liu LX, Murray S, Han MK, Kazerooni EA, et al. Clinical predictors of a diagnosis of idiopathic pulmonary fibrosis. Am J Respir Crit Care Med 2010;181:832-7.

40. Naidoo N. ER and aging-Protein folding and the ER stress response. Ageing Res Rev 2009;8:150-9.

41. Korfei M, Ruppert C, Mahavadi P, Henneke I, Markart P, Koch M, et al. Epithelial endoplasmic reticulum stress and apoptosis in sporadic idiopathic pulmonary fibrosis. Am J Respir Crit Care Med 2008;178:838-46.

42. Lawson WE, Crossno PF, Polosukhin VV, Roldan J, Cheng DS, Lane KB, et al. Endoplasmic reticulum stress in alveolar epithelial cells is prominent in IPF: association with altered surfactant protein processing and herpesvirus infection. Am J Physiol Lung Cell Mol Physiol 2008;294:L1119-26.

43. Wang Y, Kuan PJ, Xing C, Cronkhite JT, Torres F, Rosenblatt RL, et al. Genetic defects in surfactant protein A2 are associated with pulmonary fibrosis and lung cancer. Am J Hum Genet 2009;84:52-9.

44. Jones DP. Extracellular redox state: refining the definition of oxidative stress in aging. Rejuvenation Res 2006;9:169-81.

45. Mora AL, Rojas M. Aging and lung injury repair: a role for bone marrow derived mesenchymal stem cells. J Cell Biochem 2008;105:641-7.

46. Han MK, Murray S, Fell CD, Flaherty KR, Toews GB, Myers J, et al. Sex differences in physiological progression of idiopathic pulmonary fibrosis. Eur Respir J 2008;31:1183-8.

47. Steele MP, Speer MC, Loyd JE, Brown KK, Herron A, Slifer $\mathrm{SH}$, et al. Clinical and pathologic features of familial intersti- tial pneumonia. Am J Respir Crit Care Med 2005;172:114652.

48. Samara KD, Margaritopoulos G, Wells AU, Siafakas NM, Antoniou KM. Smoking and pulmonary fibrosis: novel insights. Pulm Med 2011;2011:461439.

49. Spira A, Beane J, Shah V, Liu G, Schembri F, Yang X, et al. Effects of cigarette smoke on the human airway epithelial cell transcriptome. Proc Natl Acad Sci U S A 2004;101:10143-8.

50. Yang IV, Schwartz DA. Epigenetics of idiopathic pulmonary fibrosis. Transl Res 2015;165:48-60.

51. Molyneaux PL, Maher TM. The role of infection in the pathogenesis of idiopathic pulmonary fibrosis. Eur Respir Rev 2013;22:376-81.

52. Isler JA, Skalet AH, Alwine JC. Human cytomegalovirus infection activates and regulates the unfolded protein response. J Virol 2005;79:6890-9.

53. Lok SS, Haider Y, Howell D, Stewart JP, Hasleton PS, Egan JJ. Murine gammaherpes virus as a cofactor in the development of pulmonary fibrosis in bleomycin resistant mice. Eur Respir J 2002;20:1228-32.

54. Knippenberg S, Ueberberg B, Maus R, Bohling J, Ding N, Tort Tarres M, et al. Streptococcus pneumoniae triggers progression of pulmonary fibrosis through pneumolysin. Thorax 2015;70:636-46.

55. Thannickal VJ, Zhou Y, Gaggar A, Duncan SR. Fibrosis: ultimate and proximate causes. J Clin Invest 2014;124:4673-7.

56. Daniil Z, Kitsanta P, Kapotsis G, Mathioudaki M, Kollintza A, Karatza M, et al. CD8+ T lymphocytes in lung tissue from patients with idiopathic pulmonary fibrosis. Respir Res 2005;6:81.

57. Kolb M, Margetts PJ, Anthony DC, Pitossi F, Gauldie J. Transient expression of IL-1beta induces acute lung injury and chronic repair leading to pulmonary fibrosis. J Clin Invest 2001;107:1529-36.

58. Evans CM, Fingerlin TE, Schwarz MI, Lynch D, Kurche J, Warg L, et al. Idiopathic pulmonary fibrosis: a genetic disease that involves mucociliary dysfunction of the peripheral airways. Physiol Rev 2016;96:1567-91.

59. Kropski JA, Blackwell TS, Loyd JE. The genetic basis of idiopathic pulmonary fibrosis. Eur Respir J 2015;45:1717-27.

60. Lee JS, Collard HR, Raghu G, Sweet MP, Hays SR, Campos GM, et al. Does chronic microaspiration cause idiopathic pulmonary fibrosis? Am J Med 2010;123:304-11.

61. Lee JS. The Role of Gastroesophageal Reflux and microaspiration in idiopathic pulmonary fibrosis. Clin Pulm Med 2014;21:81-5.

62. Raghu G, Yang ST, Spada C, Hayes J, Pellegrini CA. Sole treatment of acid gastroesophageal reflux in idiopathic pulmonary fibrosis: a case series. Chest 2006;129:794-800.

63. Raghu G, Morrow E, Collins BF, Ho LA, Hinojosa MW, Hayes JM, et al. Laparoscopic anti-reflux surgery for idiopathic pulmonary fibrosis at a single centre. Eur Respir J 2016;48:82632. 
64. Kreuter M, Wuyts W, Renzoni E, Koschel D, Maher TM, Kolb M, et al. Antacid therapy and disease outcomes in idiopathic pulmonary fibrosis: a pooled analysis. Lancet Respir Med 2016;4:381-9.

65. Flaherty KR, King TE Jr, Raghu G, Lynch JP 3rd, Colby TV, Travis WD, et al. Idiopathic interstitial pneumonia: what is the effect of a multidisciplinary approach to diagnosis? Am J Respir Crit Care Med 2004;170:904-10.

66. Taniguchi H, Ebina M, Kondoh Y, Ogura T, Azuma A, Suga M, et al. Pirfenidone in idiopathic pulmonary fibrosis. Eur Respir J 2010;35:821-9.

67. Noble PW, Albera C, Bradford WZ, Costabel U, Glassberg MK, Kardatzke D, et al. Pirfenidone in patients with idiopathic pulmonary fibrosis (CAPACITY): two randomised trials. Lancet 2011;377:1760-9.

68. King TE Jr, Bradford WZ, Castro-Bernardini S, Fagan EA, Glaspole I, Glassberg MK, et al. A phase 3 trial of pirfenidone in patients with idiopathic pulmonary fibrosis. N Engl J Med 2014;370:2083-92.

69. Richeldi L, Costabel U, Selman M, Kim DS, Hansell DM, Nicholson AG, et al. Efficacy of a tyrosine kinase inhibitor in idiopathic pulmonary fibrosis. N Engl J Med 2011;365:107987.

70. Richeldi L, du Bois RM, Raghu G, Azuma A, Brown KK, Costabel U, et al. Efficacy and safety of nintedanib in idiopathic pulmonary fibrosis. N Engl J Med 2014;370:2071-82.

71. Riddell P, Lawrie I, Winward S, Redmond K, Egan JJ. Lung transplantation and survival in idiopathic pulmonary fibrosis: an Irish perspective. Thorax 2013;68(Suppl 3):A168.

72. Thabut G, Mal H, Castier Y, Groussard O, Brugiere O, Marrash-Chahla $\mathrm{R}$, et al. Survival benefit of lung transplantation for patients with idiopathic pulmonary fibrosis. J Thorac Cardiovasc Surg 2003;126:469-75.

73. Bjoraker JA, Ryu JH, Edwin MK, Myers JL, Tazelaar HD, Schroeder DR, et al. Prognostic significance of histopathologic subsets in idiopathic pulmonary fibrosis. Am J Respir Crit Care Med 1998;157:199-203.

74. Daniels CE, Yi ES, Ryu JH. Autopsy findings in 42 consecutive patients with idiopathic pulmonary fibrosis. Eur Respir J 2008;32:170-4.

75. Song JW, Hong SB, Lim CM, Koh Y, Kim DS. Acute exacerbation of idiopathic pulmonary fibrosis: incidence, risk factors and outcome. Eur Respir J 2011;37:356-63.

76. Kim HJ, Perlman D, Tomic R. Natural history of idiopathic pulmonary fibrosis. Respir Med 2015;109:661-70.

77. National Clinical Guideline Centre. Diagnosis and management of suspected idiopathic pulmonary fibrosis: idiopathic pulmonary fibrosis. National Institute for Health and Care Excellence: clinical guidelines. NICE clinical guidelines, No. 163. London: Royal College of Physicians; 2013.

78. Ley B, Collard HR, King TE Jr. Clinical course and prediction of survival in idiopathic pulmonary fibrosis. Am J Respir Crit Care Med 2011;183:431-40.
79. Erbes R, Schaberg T, Loddenkemper R. Lung function tests in patients with idiopathic pulmonary fibrosis. Are they helpful for predicting outcome? Chest 1997;111:51-7.

80. Lederer DJ, Arcasoy SM, Wilt JS, D’Ovidio F, Sonett JR, Kawut SM. Six-minute-walk distance predicts waiting list survival in idiopathic pulmonary fibrosis. Am J Respir Crit Care Med 2006;174:659-64.

81. King TE Jr, Tooze JA, Schwarz MI, Brown KR, Cherniack RM. Predicting survival in idiopathic pulmonary fibrosis: scoring system and survival model. Am J Respir Crit Care Med 2001;164:1171-81.

82. Wells AU, Desai SR, Rubens MB, Goh NS, Cramer D, Nicholson AG, et al. Idiopathic pulmonary fibrosis: a composite physiologic index derived from disease extent observed by computed tomography. Am J Respir Crit Care Med 2003; 167:962-9.

83. du Bois RM, Weycker D, Albera C, Bradford WZ, Costabel U, Kartashov A, et al. Ascertainment of individual risk of mortality for patients with idiopathic pulmonary fibrosis. Am J Respir Crit Care Med 2011;184:459-66.

84. Patel NM, Lederer DJ, Borczuk AC, Kawut SM. Pulmonary hypertension in idiopathic pulmonary fibrosis. Chest 2007;132:998-1006.

85. Mejia M, Carrillo G, Rojas-Serrano J, Estrada A, Suarez T, Alonso D, et al. Idiopathic pulmonary fibrosis and emphysema: decreased survival associated with severe pulmonary arterial hypertension. Chest 2009;136:10-5.

86. Nadrous HF, Myers JL, Decker PA, Ryu JH. Idiopathic pulmonary fibrosis in patients younger than 50 years. Mayo Clin Proc 2005;80:37-40.

87. Alakhras M, Decker PA, Nadrous HF, Collazo-Clavell M, Ryu JH. Body mass index and mortality in patients with idiopathic pulmonary fibrosis. Chest 2007;131:1448-53.

88. Nishiyama O, Taniguchi H, Kondoh Y, Kimura T, Kato K, Kataoka K, et al. A simple assessment of dyspnoea as a prognostic indicator in idiopathic pulmonary fibrosis. Eur Respir J 2010;36:1067-72.

89. Hook JL, Arcasoy SM, Zemmel D, Bartels MN, Kawut SM, Lederer DJ. Titrated oxygen requirement and prognostication in idiopathic pulmonary fibrosis. Eur Respir J 2012;39: 359-65.

90. Collard HR, King TE Jr, Bartelson BB, Vourlekis JS, Schwarz MI, Brown KK. Changes in clinical and physiologic variables predict survival in idiopathic pulmonary fibrosis. Am J Respir Crit Care Med 2003;168:538-42.

91. Flaherty KR, Andrei AC, Murray S, Fraley C, Colby TV, Travis WD, et al. Idiopathic pulmonary fibrosis: prognostic value of changes in physiology and six-minute-walk test. Am J Respir Crit Care Med 2006;174:803-9.

92. Richeldi L, Ryerson CJ, Lee JS, Wolters PJ, Koth LL, Ley B, et al. Relative versus absolute change in forced vital capacity in idiopathic pulmonary fibrosis. Thorax 2012;67:407-11.

93. Zappala CJ, Latsi PI, Nicholson AG, Colby TV, Cramer D, 
Renzoni EA, et al. Marginal decline in forced vital capacity is associated with a poor outcome in idiopathic pulmonary fibrosis. Eur Respir J 2010;35:830-6.

94. Brown AW, Shlobin OA, Weir N, Albano MC, Ahmad S, Smith M, et al. Dynamic patient counseling: a novel concept in idiopathic pulmonary fibrosis. Chest 2012;142:1005-10.

95. du Bois RM, Albera C, Bradford WZ, Costabel U, Leff JA, Noble PW, et al. 6-Minute walk distance is an independent predictor of mortality in patients with idiopathic pulmonary fibrosis. Eur Respir J 2014;43:1421-9.

96. Simon-Blancal V, Freynet O, Nunes H, Bouvry D, Naggara N, Brillet PY, et al. Acute exacerbation of idiopathic pulmonary fibrosis: outcome and prognostic factors. Respiration 2012;83:28-35.

97. Lee HY, Lee KS, Jeong YJ, Hwang JH, Kim HJ, Chung MP, et al. High-resolution CT findings in fibrotic idiopathic interstitial pneumonias with little honeycombing: serial changes and prognostic implications. AJR Am J Roentgenol 2012;199:982-9.

98. Maldonado F, Moua T, Rajagopalan S, Karwoski RA, Raghunath S, Decker PA, et al. Automated quantification of radiological patterns predicts survival in idiopathic pulmonary fibrosis. Eur Respir J 2014;43:204-12.

99. Tiitto L, Bloigu R, Heiskanen U, Paakko P, Kinnula VL, Kaarteenaho-Wiik R. Relationship between histopathological features and the course of idiopathic pulmonary fibrosis/ usual interstitial pneumonia. Thorax 2006;61:1091-5.

100. Richards TJ, Kaminski N, Baribaud F, Flavin S, Brodmerkel C, Horowitz D, et al. Peripheral blood proteins predict mortality in idiopathic pulmonary fibrosis. Am J Respir Crit Care Med 2012;185:67-76.

101. Watters LC, King TE, Schwarz MI, Waldron JA, Stanford RE, Cherniack RM. A clinical, radiographic, and physiologic scoring system for the longitudinal assessment of patients with idiopathic pulmonary fibrosis. Am Rev Respir Dis 1986;133:97-103.

102. Mura M, Porretta MA, Bargagli E, Sergiacomi G, Zompatori $\mathrm{M}$, Sverzellati N, et al. Predicting survival in newly diagnosed idiopathic pulmonary fibrosis: a 3-year prospective study. Eur Respir J 2012;40:101-9.

103. Ley B, Ryerson CJ, Vittinghoff E, Ryu JH, Tomassetti S, Lee JS, et al. A multidimensional index and staging system for idiopathic pulmonary fibrosis. Ann Intern Med 2012;156:68491.
104. Kim ES, Choi SM, Lee J, Park YS, Lee CH, Yim JJ, et al. Validation of the GAP score in Korean patients with idiopathic pulmonary fibrosis. Chest 2015;147:430-7.

105. Raghu G. Idiopathic pulmonary fibrosis: guidelines for diagnosis and clinical management have advanced from consensus-based in 2000 to evidence-based in 2011. Eur Respir J 2011;37:743-6.

106. Collard HR, Moore BB, Flaherty KR, Brown KK, Kaner RJ, King TE Jr, et al. Acute exacerbations of idiopathic pulmonary fibrosis. Am J Respir Crit Care Med 2007;176:636-43.

107. Park IN, Kim DS, Shim TS, Lim CM, Lee SD, Koh Y, et al. Acute exacerbation of interstitial pneumonia other than idiopathic pulmonary fibrosis. Chest 2007;132:214-20.

108. Kim DS, Park JH, Park BK, Lee JS, Nicholson AG, Colby T. Acute exacerbation of idiopathic pulmonary fibrosis: frequency and clinical features. Eur Respir J 2006;27:143-50.

109. Akira M, Hamada H, Sakatani M, Kobayashi C, Nishioka M, Yamamoto S. CT findings during phase of accelerated deterioration in patients with idiopathic pulmonary fibrosis. AJR Am J Roentgenol 1997;168:79-83.

110. Konishi K, Gibson KF, Lindell KO, Richards TJ, Zhang Y, Dhir $\mathrm{R}$, et al. Gene expression profiles of acute exacerbations of idiopathic pulmonary fibrosis. Am J Respir Crit Care Med 2009;180:167-75.

111. Collard HR, Calfee CS, Wolters PJ, Song JW, Hong SB, Brady $\mathrm{S}$, et al. Plasma biomarker profiles in acute exacerbation of idiopathic pulmonary fibrosis. Am J Physiol Lung Cell Mol Physiol 2010;299:L3-7.

112. Wootton SC, Kim DS, Kondoh Y, Chen E, Lee JS, Song JW, et al. Viral infection in acute exacerbation of idiopathic pulmonary fibrosis. Am J Respir Crit Care Med 2011;183:1698-702.

113. Johannson KA, Vittinghoff E, Lee K, Balmes JR, Ji W, Kaplan GG, et al. Acute exacerbation of idiopathic pulmonary fibrosis associated with air pollution exposure. Eur Respir J 2014; 43:1124-31.

114. Collard HR, Ryerson CJ, Corte TJ, Jenkins G, Kondoh Y, Lederer DJ, et al. Acute Exacerbation of Idiopathic Pulmonary Fibrosis. An International Working Group Report. Am J Respir Crit Care Med 2016;194:265-75.

115. Noth I, Anstrom KJ, Calvert SB, de Andrade J, Flaherty KR, Glazer C, et al. A placebo-controlled randomized trial of warfarin in idiopathic pulmonary fibrosis. Am J Respir Crit Care Med 2012;186:88-95. 